\title{
Determining the Accuracy and Reliability of Indirect Calorimeters Utilizing the
}

\section{Methanol Combustion Technique}

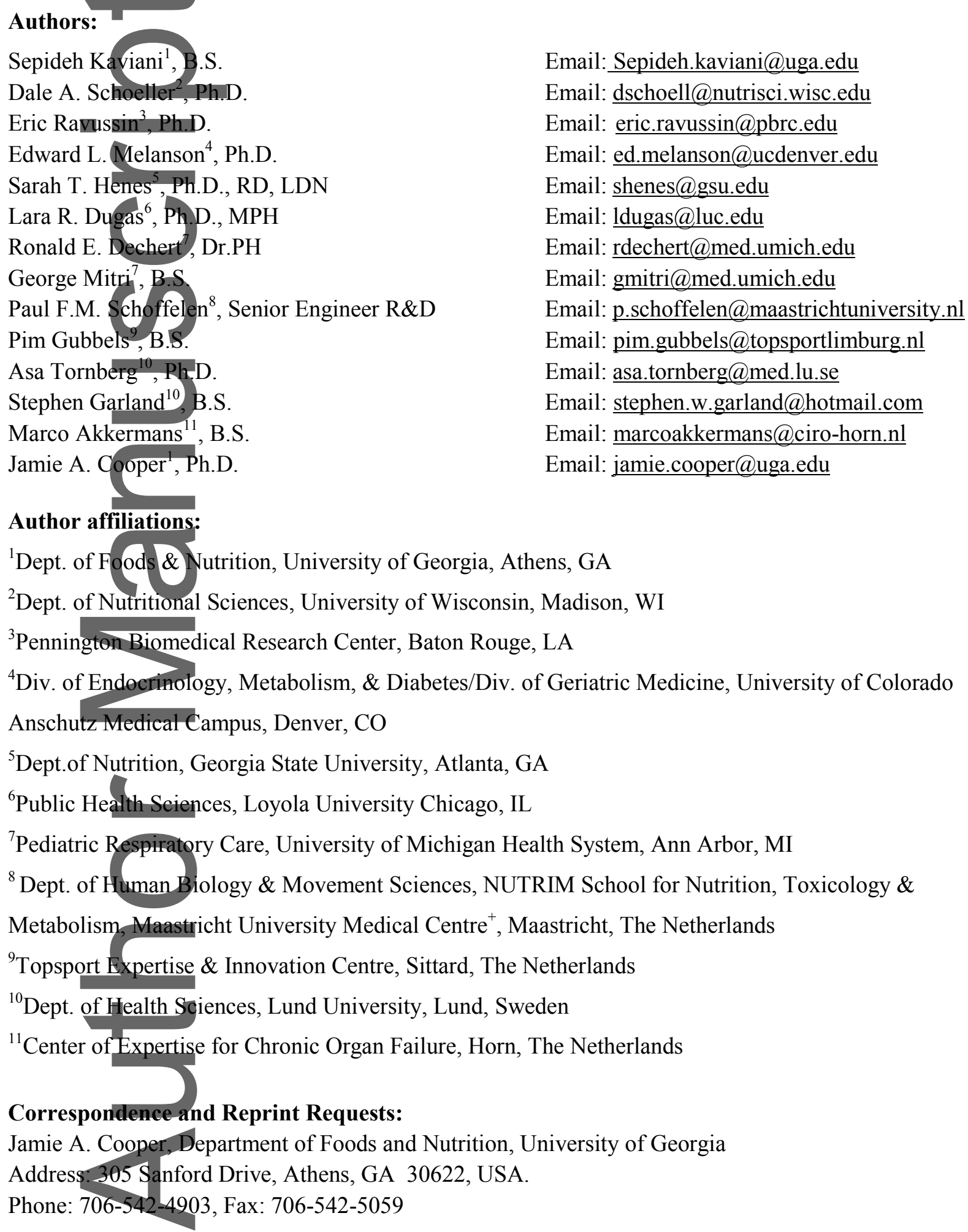

This is the author manuscript accepted for publication and has undergone full peer review but has not been through the copyediting, typesetting, pagination and proofreading process, which may lead to differences between this version and the Version of Record. Please cite this article as doi: 10.1002/ncp.10070.

This article is protected by copyright. All rights reserved. 
Email: jamie.cooper@uga.edu

Funding: This research was supported by a grant from Colorado Nutrition and Obesity Research Center (P30 DK048520), and Colorado Clinical and Translational Science Institute (UL1 RR025780).

Disclosure All authors declare that there were no conflicts of interest.

Background: A variety of indirect calorimetry (IC) ${ }^{1}$ instruments are commercially available, but comparative yalidity and reliability data is lacking. Existing data is limited by inconsistencies in protocols, subject characteristics, or single-instrument validation comparisons. Aim: Compare accuracy and reliability of metabolic carts using methanol combustion as the cross-laboratory criterion. Methods: Eight, 20-minute methanol burn trials were completed on 12 metabolic carts at 11 international sites. Respiratory Exchange Ratio (RER) and pereent $\mathrm{O}_{2}$ and $\mathrm{CO}_{2}$ recovery were calculated. Results: Accuracy-1 Omnical, Cosmed and both Parvos measured all 3 variables within $2 \%$ of the true value; both DeltaTracs and the Vmax Encore showed similar accuracy in measuring one or two, but not all, variables. Reliability -8 instruments were shown to be reliable with the two Omnicals ranking best (coefficient of variation $(\mathrm{CV})^{2}<1.26 \%$ ). Both Cosmeds, Parvos, DeltaTracs, 1 Oxycon, Max-II and Vmax were reliable for at least one variable $(\mathrm{CV}(\mathrm{s}) \leq 3 \%)$. Multiple Regression-Humidity and amount of combusted methanol were significant predictors of RER $\left(\mathrm{R}^{2}=0.33, \underline{\mathrm{p}<0.001}\right)$. Temperature and amount of burned methanol were significant predictors of $\mathrm{O}_{2}$ recovery $\left(\mathrm{R}^{2}=0.18, \mathrm{p}<0.001\right)$; only humidity was a predictor for $\mathrm{CO}_{2}$ recovery $\left(\mathrm{R}^{2}=0.15, \mathrm{p}<0.001\right)$. Conclusions: 4 indirect calorimeters (Omnical, Parvo, Cosmed and

\footnotetext{
${ }^{1}$ Indirect Calorimetry

${ }^{2}$ Coefficient of Variation
}

This article is protected by copyright. All rights reserved. 
DeltaTrac) had greater accuracy and reliability of the 12 tested. The small number of instruments tested and expected differences in gas calibration variability limits the generalizability of conclusions. Finally, humidity and temperature may influence instrument performance and could be modified in the lab to optimize IC conditions.

Key Words: Metabolic cart, reliability, accuracy, indirect calorimetry, methanol burn

\section{Introduction}

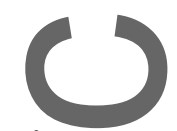

Oxygen consumption and carbon dioxide production measurements obtained from indirect calorimetry (IC) in humans are used to measure energy expenditure (EE) ${ }^{1-3}$ and calculate substrate utilization using the respiratory exchange ratio $\left(\mathrm{RER}=\mathrm{VCO}_{2} / \mathrm{VO}_{2}\right)^{2,4}$ to calculate macronutrient oxidation ${ }^{5}$. Metabolic carts are mobile and have a small footprint so they are commonly used in research and clinical settings ${ }^{2}$. To measure fasting, exercise, and postprandial EE and substrate oxidation, it is crucial to have an instrument that is both reliable and accurate. Reliability refers to the extent to which an instrument is able to produce similar results on repeated measurements, whereas accuracy explains how close a measurement is to the actual or true value. A few previous studies have examined the accuracy and reliability of different metabolic carts by comparing resting metabolic rate (RMR) and RER measures using multiple metabolic carts with repeated tests performed on human participants ${ }^{4,6-8}$. This method of assessment considers one instrument as the most accurate, i.e. the criterion. Then, the accuracy of other instruments is tested based on how close to this criterion they can measure metabolic data. If the criterion itself is validated with methanol burns, it is considered accurate; however, this is not always done. By using human participants from yarying populations, past studies have revealed that indirect calorimeters show a certain degree of inaccuracy in measuring RER. Further, they can have a large within- 
subject variability for resting energy expenditure (REE), even with inter-unit variability testing ${ }^{4,6-8}$. Moreover, these studies are often done first thing in the morning in fasting human subjects with no multiple measures within a day to investigate across-day variation ${ }^{4,9}$. Due to inconsistencies in previous methodological assessments and the absence of data on accuracy for severaltypes of metabolic carts, research is needed to eliminate potential causes of subject-related variance by using a common chemical burn as the benchmark.

Alcoholcombustion with methanol or ethanol is routinely used to validate the accuracy of metabolic carts as well as correct data after it has been collected ${ }^{4,8,10-12}$. Methanol combustion has a well-defined theoretical value of $\mathrm{O}_{2}$ and $\mathrm{CO}_{2}$. It can therefore be used to determine accuracy and reliability of a metabolic cart while eliminating some of the aforementioned confounding variables. The purpose of this study was to determine the accuracy or reliability of several different metabolic carts using methanol combustion technique. Since the DeltaTrac II (DTC) has previously been considered a gold standard instrument, we hypothesized that it would be the most accurate and reliable instrument ${ }^{4,13,14}$. We also hypothesized that there would be a high degree of variability indicating low reliability across two testing days.

\section{Materials and Methods}

\section{Instruments and Collaborators}

Researchers owning metabolic carts with methanol burn capabilities around the U.S. and Europe were contacted to collaborate. Two sites for each instrument were identified for all instruments except the Vmax Encore (Carefusion, Yorba Linda, CA, USA), and Max-II (AEI Technologies Pittsburgh, PA, USA) metabolic carts. Table 1 shows all instruments and study sites along with an abbreviated name for each instrument which will be used throughout the manuscript. To perform the methanol burns, all of the instruments use a glass 
alcohol container with a wick, inside a ventilated glass canopy to burn methanol, except for the Max-II, the DTC, and the Cosmed Quark CPET, which use a crucible in the ventilated glass canopy. Table 4 shows more details about each instrument's characteristics.

\section{Study Protocol}

A 500mL unopened bottle of Methanol (A412500 Certified American Chemical

$$
\text { ( }
$$

Society, 0.1\% Max. water) (Fisher Scientific, Asheville, NC, USA) was sent by the lead researchers to each site. All testing was done with methanol from the same lot number. Prior

to the two-day testing protocol, each researcher with the glass canopy wick burning kit performed multiple methanol burns to achieve the wick height that equaled an EE of 1.0 $\mathrm{kcal} / \mathrm{min}$, which is a similar rate of human adult EE per minute at rest ${ }^{15-17}$. It was not possible to manipulate the burn rate with the crucible.

Testing was completed on two consecutive days, and methanol burns were performed $1000,130($ at $0700,1000,1300$, and 1600 hours, local time. Data was used to determine accuracy and reliability across and between testing days. Each instrument was calibrated prior to testing according to manufacturer specifications. A fan was also kept running in the room to minimize variability in ambient air secondary to human activity. The parameters including room temperature, humidity, barometric pressure, and the amount of methanol burned were recorded for each burn. The flame was lit as soon as the program was started on the computer. The first minute of data collection was discarded since the combusted methanol had not yet filled the glass canopy of the burn kit and values were similar to room gas. At the $20^{\text {th }}$ minute of methanol burning, the glass canopy of the burn kit was lifted, the flame was blown out, and the canopy was replaced as quickly as possible for the final minute of data collection. The methanol weight was not dynamically measured and recorded during the burn. Rather, methanol weight was recorded immediately before and immediately upon completion of the burn using a routinely calibrated gram scale. The methanol burn test for 
each site were performed by the same researcher using the aforementioned procedures. All data collected during the 20-minute burn was used for final data analysis.

\section{Calculations}

Percent reeoveries of both $\mathrm{O}_{2}$ and $\mathrm{CO}_{2}$ as well as RER were calculated by previously published formulas ${ }^{18}$. The theoretical value for percent $\mathrm{O}_{2}$ and $\mathrm{CO}_{2}$ recovery was $100 \%$, and the theoretical value for RER was 0.667 based on the ratio of produced $\mathrm{CO}_{2}$ to utilized $\mathrm{O}_{2}$ in the burning of methanol from this equation: $2 \mathrm{CH}_{3} \mathrm{OH}+3 \mathrm{O}_{2} \rightarrow 2 \mathrm{CO}_{2}+4 \mathrm{H}_{2} \mathrm{O}$, which is the value regardless of fuel infusion rate and/or changes in fraction of inspired oxygen $\left(\mathrm{FiO}_{2}\right)^{19}$.

\section{Statistical Analysis}

Data were analyzed using SAS Version 9.4 (SAS Institute Inc., Cary, NC). No statistical analyses were performed on a between-site basis. To test accuracy, average values of each of the three variables (RER, percent $(\%)$ recovery $\mathrm{O}_{2}$ and $\%$ recovery $\mathrm{CO}_{2}$ ) throughout the 8 time points obtained from each instrument were compared to the above mentioned theoretical values for methanol. The percent of relative error $(\% \mathrm{RE})$ was calculated as $\left(\frac{\text { Average of Measured Values-Theoretical Value }}{\text { Theoretical Value }}\right) \times 100$. The instruments were ranked from lowest to highest based on \%RE. The use of \%RE to show accuracy helps assess the distance of the average values measured by the instruments from the theoretical value, regardless of variability throughout multiple measurements. Eliminating the variability from ren assessments of accuracy allows the proper separation of accuracy and reliability given the previously mentioned differences in their definitions. Because there is no agreement on the constant value to be used in calculating RMR and substrate oxidation ${ }^{20}$, we elected to use $2 \%$ difference from the theoretical as the accuracy threshold for measured RER (RER range of 0.653-0.680) and gas recovery (recovery range of 98-102\%) because such an estimated, but 
defendable, approach implies that smaller differences are probably not biologically important. To obtain the cutoff point of $2 \%$ for RE, we pursued an empirical approach by calculating the median SD across instruments for each of the three variables and then a 95\% CI for SD. Further, a $95 \%$ CI for $\%$ RE was calculated for each variable. Those values were $0.94 \%$, $2.21 \%$ and $1.79 \%$ for RER, $\%$ recovery $\mathrm{O}_{2}$ and $\%$ recovery $\mathrm{CO}_{2}$, respectively. The smaller RER co 95\% CI for RER compared to $\mathrm{O}_{2}$ and $\mathrm{CO}_{2}$ suggests a flow rate calibration error although incomplete methanol combustion is another possible explanation.

To measure reliability, the coefficient of variation $(\mathrm{CV})$ was calculated for each lab instrument pair to assess the amount of variability relative to the average values of RER, \% recovery $\mathrm{O}_{2}$ and $\%$ recovery $\mathrm{CO}_{2}$. CV less than $3 \%$ was selected as the upper limit threshold of reliability ${ }^{4}$. Since a $4 \%$ variability from one day to another is reported for human subjects ${ }^{21}$, it is suggested that an ideal gas analysis system needs to have a CV of less than $3 \%$ in order to not grossly inflate the day to day variation in RMR from a given individual ${ }^{4}$.

Finally, a step-wise multiple regression was used to assess which environmental or exogenous factors could explain the majority of the variance in our outcome measures. Factors used in the model included humidity, temperature, and the amount of methanol utilized in each burn. We also performed single regression to see how geographic elevation of the testing site and age of the instruments were correlated with outcome measures. The latter two variables were not included in the multiple regression model because they remained constant throughout the 8 time points of instrument testing whereas the other factors showed variation from one burn to the next.

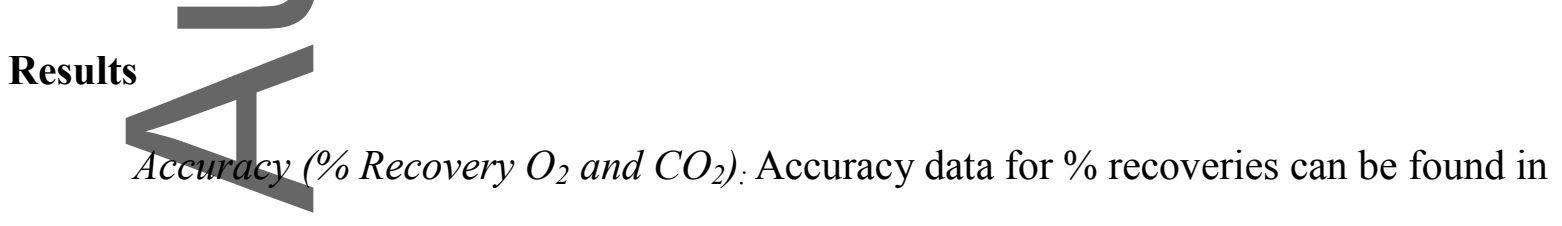
Table 2, Figures 1 and Figure 2. Six out of the twelve instruments measured $\%$ recovery $\mathrm{O}_{2}$ within the $\pm 2 \%$ difference $(\% \mathrm{RE} \leq 2)$ from the true value $\left(\right.$ Omnicall $\left(\mathrm{O}_{2}\right.$ 
recovery $=100.1 \pm 0.8 \% ; \% \mathrm{RE}=0.1)$, Parvo $(\mathrm{O} 2$ recovery $=0.99 \pm 0.02 ; \% \mathrm{RE}=0.65), \mathrm{Cosmed} 2$ $\left(\mathrm{O}_{2}\right.$ recovery $\left.=99.8 \pm 2.1 \% ; \% \mathrm{RE}=-0.3\right), \mathrm{DTC} 2\left(\mathrm{O}_{2}\right.$ recovery $\left.=100.8 \pm 2.4 \% ; \% \mathrm{RE}=0.8\right)$, Parvo2 $\left(\mathrm{O}_{2}\right.$ recovery $\left.=101.2 \pm 2.9 \% ; \% \mathrm{RE}=1.2\right)$, and Vmax Encore $\left(\mathrm{O}_{2}\right.$ recovery $=101.8 \pm 5.1 \%$; $\% \mathrm{RE}=1.8)$ ). Seven out of 12 instruments measured $\%$ recovery $\mathrm{CO}_{2}$ within the $\pm 2 \%$ difference $(\% \mathrm{RE} \leq 2)$ from the true value (Parvo2 $\left(\mathrm{CO}_{2}\right.$ recovery= $\left.100.1 \pm 3.2 \% ; \% \mathrm{RE}=0.1\right)$, Parvo1 (CQ2 recovery $=0.99 \pm 0.02 ; \% \mathrm{RE}=-0.53)$, Cosmed $\left(\mathrm{CO}_{2}\right.$ recovery $=100.7 \pm 1.7 \%$; $\% \mathrm{RE}=0.7), \mathrm{DTC1}\left(\mathrm{CO}_{2}\right.$ recovery=100.7 $\pm 1.5 \%$; \% $\left.\mathrm{RE}=0.7\right)$, Vmax Encore $\left(\mathrm{CO}_{2}\right.$ recovery $=98.4 \pm 2.1 \%, \% \mathrm{RE}=-1.6)$, Omnical $\left(\mathrm{CO}_{2}\right.$ recovery $\left.=101.6 \pm 0.8 \%, \% \mathrm{RE}=1.6\right)$, and DTC2 $\left(\mathrm{CO}_{2}\right.$ recovery $\left.\left.=98.1 \pm 3.8 \%, \% \mathrm{RE}=-1.9\right)\right)$. Therefore, the Omnical1, Cosmed2, DTC2, Parvo 2 and $\operatorname{Vmax}$ Encore were accurate for both $\mathrm{O}_{2}$ and $\mathrm{CO}_{2}$ recoveries while DTC1 was only accurate for $\%$ recovery $\mathrm{CO}_{2}$ and not for $\mathrm{O}_{2}$.

Accuracy (RER): The average RER across the 2 study days was compared to the theoretical value for methanol (0.667) to determine accuracy (Table 2 and Figure 3). Among all 12 instruments, only five instruments measured RER within the $\pm 2 \%$ difference $(\% \mathrm{RE} \leq 2)$ from the true value (Omnical2 $(\mathrm{RER}=0.667 \pm 0.002 ; \% \mathrm{RE}=0.0)$, Parvo1 $(\mathrm{RER}=0.668 \pm 0.006$, $\% \mathrm{RE}=0.126)$, Cosmed $2(\mathrm{RER}=0.673 \pm 0.005 ; \% \mathrm{RE}=0.9)$, and Parvo2 $(\mathrm{RER}=0.660 \pm 0.005$; $\% \mathrm{RE}=-1.0$, Omnical1 $(\mathrm{RER}=0.677 \pm 0.003 ; \% \mathrm{RE}=1.5)$, and $)$. The other 7 instruments had $\% \mathrm{RE}>2$ for RER.

Finally, all of the instruments were rank ordered from closest to theoretical to the furthest from theoretical according to the $\%$ RE. These results can be found in Table 2 . For $\%$ recovery $\mathrm{O}_{2}$, Omnical1, Parvo 1 and Cosmed 2 had the least \% $\mathrm{RE}$, respectively; and for \% recovery $\mathrm{CO}_{2}$, Parvo2, Parvo1 and Cosmed 2 had the least \%RE respectively, indicating these to be the top/better metabolic carts tested for accuracy in this study. For RER, Omnical2, Parvo 1 and Cosmed 2 had the least \%RE respectively. 


\section{Reliability}

For $\%$ recovery $\mathrm{O}_{2}, 8$ out of 12 instruments (both Omnicals, Cosmeds, DeltaTracs and Parvos) were shown to be reliable with Omnical1 ( $\mathrm{CV}=0.75 \%)$, Omnical2 ( $\mathrm{CV}=1.26 \%)$ and Parvot ( $\mathrm{CV}=1.56 \%$ ) being the three most reliable carts. For \% recovery $\mathrm{CO}_{2}, 9$ out of 12 instruments (both Omnicals, Cosmeds, the DTC1, Parvo1, Vmax, Max-II and Oxycon1) were reliable with Omnical1 (CV=0.76\%), Omnical2 $(\mathrm{CV}=1.21 \%)$ and Cosmed1 $(\mathrm{CV}=1.22 \%)$ being the three most reliable metabolic carts with the smallest CVs. For RER, 8 out of 12 instruments (both Omnicals, Cosmeds, Parvos, the DTC1 and Oxycon1) were considered reliable $(\mathrm{CV} \leq 3 \%)$ with Omnical2 $(\mathrm{CV}=0.23 \%)$, Omnical1 $(\mathrm{CV}=0.49 \%)$ and Cosmed 2 $(\mathrm{CV}=0.68 \%)$ being the three most reliable carts, respectively (Table 3). The CV calculation was based-on all 8 tests for each instrument. Range of SD for RER was (0.002-0.040), for $\% \mathrm{O}_{2}$ was $(0.008-0.139)$, and for $\% \mathrm{CO}_{2}$ was $(0.008-0.144)$.

\section{Correlation and Multiple Regression}

The correlation matrix for outcome variables and exogenous factors (temperature, humidity, amount of methanol burned, age of instrument, and elevation) are shown in Table 5. Both RER and percent $\mathrm{CO}_{2}$ recovery were negatively correlated with temperature and amount of methanol burned and positively correlated with humidity. Percent $\mathrm{O}_{2}$ recovery did not correlate with any exogenous factors. Geographic elevation of instrument was not correlated with any of the outcome variables. Age of instrument was significantly correlated with RER ( $p=0.01)$, but not with gas recoveries. For the step-wise multiple regression, humidity, temperature and grams of methanol burned were included in the model with RER as dependent variable. Temperature could be removed from the model with backward elimination technique, leaving both humidity and amount of burned methanol as independent and significant positive predictors of RER, making the overall regression model significant (F $\left.(2,92)=10.91, \mathrm{p}<0.001, \mathrm{R}^{2}=0.3301\right)$. For $\%$ recovery $\mathrm{O}_{2}$, humidity was removed from the 
model with backward elimination technique, leaving temperature and amount of burned methanol as significant predictors of $\%$ recovery $\mathrm{O}_{2}$ (positive and negative predictors, respectively), making the overall regression model significant $(F(2,92)=8.32, p<0.001$, $\mathrm{R}^{2}=0.1822$ ). Finally, for $\%$ recovery $\mathrm{CO}_{2}$, both the amount of burned methanol and temperature were removed from the model leaving only humidity as a significant remaining predictor $\left(\mathrm{F}(1,92)=21.10, \mathrm{p}<0.001, \mathrm{R}^{2}=0.1498\right)$.

\section{Discussion}

In this study, one Cosmed, one Omnical, and two Parvos measured all three variables (RER and gas recoveries) within $\pm 2 \%$ difference from the theoretical, while both DeltaTracs and the one Vmax Encore showed similar accuracy in measuring one or two, but not all, variables. The Omnicals, one Parvo and one Cosmed were the highest ranked instruments for having the smallest \%RE in measuring one or two of the variables. Because only 1 or 2 instruments at different study sites were used in this project, caution should be taken when attempting to make generalizations to all metabolic carts of a particular make and model. Further, since two instruments of the same model did not always reveal similar extents of accuracy, which could have been caused from environmental differences between the two sites, researchers need to periodically perform combustion burns as part of research purposes and calibration

Reliability analysis demonstrated that both of the two Omnicals, Cosmeds and one DTC were reliable for all the three variables. Both Parvos, one Oxycon and one DTC were reliable in measuring one or two, but not all, variables. Further, Omnicals showed the least variability and hence the most reliability in measuring all variables. Note that these results are in part dependent on the calibration gas applied, which may explain a small portion of the error depending on absolute range within the gas certification.

This article is protected by copyright. All rights reserved. 
Previous studies have assessed the validity or reliability of metabolic carts through widely different methods with some conflicting results ${ }^{4,18,22-30}$. Nearly all of those studies were done in human subjects with one instrument (DTC in some cases) chosen as the criterion ${ }^{4,18}$. Cooper et al ${ }^{4}$ determined validity and reliability of five different IC systems (MedGraphics CPX Ultima, MedGem, Vmax Encore 29 System, TrueOne 2400, and Korr ReeVue) againstDTC in human subjects. They found that the Parvo (TrueOne) and Vmax were the most valid instruments in measuring RMR and RER while none of the instruments showed strong reliability. Conversely, other human studies on the Cosmed versus either the DTC ${ }^{23}$ or Douglas bag system ${ }^{22}$ as well as studies on validity of Oxycon Pro against the Douglas bag method ${ }^{24,26-30}$ concluded that both instruments were equally as accurate and reliable. The fact that DTC was not the superior instrument in our experiment sheds light on the limitation of using a metabolic cart as the gold standard instrument when testing the validity of several different IC instruments because one cannot demonstrate superiority, just equivalence.

One question faced by researchers is whether RER or \% recoveries are more important? We contend that the \% recoveries for $\mathrm{O}_{2}$ and $\mathrm{CO}_{2}$, required for determining $\mathrm{EE}$, are more important. However, both must be as reproducible as possible for supporting intervention studies. RER can be deemed less important due to the nature of the RER calculation being a ratio. If both $\mathrm{O}_{2}$ and $\mathrm{CO}_{2}$ are either over- or under-recovered, this would not affect the ratio of these two gases (RER). Additionally, the RER may be affected by calibration gas accuracy, specifically if $\mathrm{O}_{2}$ and $\mathrm{CO}_{2}$ have opposite deviation of certificate though within certificate accuracy. Ultimately, $\mathrm{O}_{2}$ has the largest impact on EE (4 times that of $\mathrm{CO}_{2}$ ). Therefore, it may be important to evaluate the accuracy of IC systems primarily on gas recovery of $\mathrm{O}_{2}$, then $\mathrm{CO}_{2}$, then RER. 
A second question facing researchers is how to determine if IC outcomes will be able to detect the possibly small impact of an intervention where the effect size depends on the (1) $\% \mathrm{CV}$ of the IC. In this study, we used $2 \%$ as the cutoff for determining accuracy. To translate this into a biological context, we calculated what a $2 \%$ margin of error means for an example of RMR, RER, and diet-induced thermogenesis (DIT) in humans. If RMR is $1500 \mathrm{Kcal} / \mathrm{d}$, a $2 \% \mathrm{RE}$ around this value equals the range of $1470-1530 \mathrm{Kcal}$. Although seemingly small, this degree of an error (range of 30-60 Kcals) could correspond to a considerably inaccurate estimation of an individual's total daily energy expenditure (TDEE) since RMR is then multiple by an activity factor to estimate TDEE. Further, very small energy surpluses (as little as 8-9 Kcals/d), if not compensated over time, has been shown to result in the average annual weight gain of $1 \mathrm{~kg}^{31}$. It is possible that some of the instruments with a $3 \%$ or $4 \%$ error in this study would also be acceptable for RMR measurements. Conversely, greater than a $2 \%$ RE (range of 0.026) for RER could be important because studies have reported significant treatment effects on changes of as low as 0.02 or $0.03^{32-34}$. A difference in RER of 0.02 can be detected in the accurate instruments; however, those with a $\%$ RE worse than $2 \%$ could easily mask that small biological difference. A similar case can be made for DIT since significant, but small, differences are often reported ${ }^{35}$.

Based on some of the variability in instrument performance at different sites, we examined possible environmental underlying factors that could influence accuracy or reliability. The results showing humidity and temperature as predictors for at least one outcome measure were somewhat surprising because the instruments are designed to account/correet for temperature and humidity. Therefore, the lack of accuracy and/or reliability for some of these instruments may lie partly in the inability to correctly account for humidity and temperature, and improvements on adjusting for these factors is warranted. We do want to note, however, that the magnitude of variance explained by these exogenous 
factors was fairly small (15-33\% depending on outcome variable), so this data should be interpreted with a small degree of caution. Since these small effect on instrument performance can add up to become biologically important, researchers should also consider regulating room humidity and temperature to improve instrument performance. In this study, we had a fairly large range of humidity and temperature during testing days across instruments $\left(24.1-68.2 \%\right.$ for humidity; $16.9-26^{\circ} \mathrm{C}$ for temperature), which explained a small percentage of the variation, so if researchers can keep these variables somewhat consistent from day to day, they are less likely to negatively impact accuracy and reliability.

\section{Study Limitations}

We only tested 2 instruments of the same model, some of which varied drastically in their performance between two study sites, which indicates that more than 2 instruments per model might achieve more conclusive findings. We also used burn kits instead of the actual chambers/hoods that are used for human subjects. An attempt to have an open flame inside the plastic canopy hood instead of the glass hood which is used for the methanol burns resulted in melting of the plastic canopy or extremely poor gas recoveries, possibly due to protective layers and ice being used on the plastic hood. However, researchers that use methanol burn data from the glass hoods observe complete combustion of methanol and measure true combusted amounts by weight, thus the accuracy and reliability of that system was still important. We are operating under the assumption that $100 \%$ combustion occurred, which is the assumption routinely used for researchers who regularly perform alcohol burns for calibration purposes. Further, the alcohol combustion kit is often the only cost-effective option available, and is proposed as validation by manufacturers of breath-by-breath IC units. Another limitation could be the burn rate. We attempted to have all the collaborators burn methanol at a certain rate to equal about $1.0 \mathrm{Kcal} / \mathrm{min}$, which is similar to human metabolic IC data; however, not every site was able to achieve this. While the theoretical gas values 
from methanol combustion should be independent of fuel infusion rate, the amount of methanol was shown to have a small impact on the $\%$ recovery $\mathrm{O}_{2}$. This is a typical effect in IC as noted for whole room calorimetry by Murgatroyd and colleagues ${ }^{36}$.

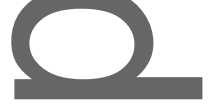

\section{Conclusion}

Within the limits of the small number of instruments we tested, the Omnical, Parvo, Cosmed, and DeltaTrac were determined to be the most accurate and reliable instruments; however, accuracy was only shown at one of the two study sites, and not for all variables. Omnical and Cosmed showed reliability at both study sites for all three outcome measures. Exogenous factors such as humidity and temperature may influence instrument performance despite that IC systems are designed to correct for such environmental elements. Although this may have a relatively small effect on instrument performance, those small effects can add up and possibly become biologically important. Therefore, in addition to the typical requirement for stable background gas fractions, humidity and temperature could be modified in the laboratory to improve IC conditions. The fact that the comparisons made in this study are not generalizable to all the manufactured instruments of the above discussed models highlights the importance of cautious interpretations of the findings. Importantly, though, the findings do allow researchers to evaluate their own results in comparison to what was found here. The importance of performing periodic methanol burns in every lab as part of the instrument testing of accuracy and precision is a necessary step towards maximizing instrument performance and providing valid results in research. This relatively small sample provided by researchers in the field is only a first step in defining and clarifying validity and its problems in IC equipment. Future research will be needed using a similar or preferably larger scale approach of validating IC instruments, to further assess validity and reliability both in technical equipment and for measuring human participants. 
Conflict of Interest: The authors declare no conflicts of interest.

\section{References}

1. Weir JdV. New methods for calculating metabolic rate with special reference to protein metabolism. $J$ Physiol. 1949;109(1-2):1.

2. Matarese LE. Indirect calorimetry: technical aspects. J Am Diet Assoc. 1997;97(10):S154-S160.

3. Lam Y, Ravussin E. Indirect calorimetry: an indispensable tool to understand and predict obesity. Eur J Clin Nutr. 2016.

4. Cooper JA, Watras AC, O'Brien MJ, et al. Assessing validity and reliability of resting metabolic rate in six gas analysis systems. J Am Diet Assoc. 2009;109(1):128-132.

5. Frayn K. Calculation of substrate oxidation rates in vivo from gaseous exchange. $J$ Appl Physiol. 1983;55(2):628-634.

6. Crouter SE, Antczak A, Hudak JR, DellaValle DM, Haas JD. Accuracy and reliability of the ParvoMedics TrueOne 2400 and MedGraphics VO2000 metabolic systems. Eur J Appl Physiol. 2006;98(2):139-151.

7. Macfarlane D, Wu H. Inter-unit variability in two ParvoMedics TrueOne 2400 automated metabolic gas analysis systems. Eur J Appl Physiol. 2013;113(3):753-762.

8. Welch W, Strath S, Swartz A. Congruent Validity and Reliability of Two Metabolic Systems to Measure Resting Metabolic Rate. Int J Sports Med. 2015;36(5):414-418.

9. St- Onge MP, Rubiano F, Jones A, Heymsfield SB. A New Hand- Held Indirect Calorimeter to Measure Postprandial Energy Expenditure. Obes Res. 2004;12(4):704-

10. Fraipont V, Preiser J-C. Energy estimation and measurement in critically ill patients. JPEN. 2013;37(6):705-713. 
11. Damask M, Weissman C, Askanazi J, Hyman A, Rosenbaum S, Kinney J. A systematic method for validation of gas exchange measurements. Anesthesiology. $1982 ; 57(3): 213-218$.

12. White MS, Shepherd JA, McEniery JA. Energy expenditure in 100 ventilated, critically ill children: improving the accuracy of predictive equations. Crit Care Med. 2000;28(7):2307-2312.

13. Alam D, Hulshof $\mathrm{P}$, Roordink D, et al. Validity and reproducibility of resting metabolic rate measurements in rural Bangladeshi women: comparison of measurements obtained by Medgem ${ }^{\mathrm{TM}}$ and by Deltatrac ${ }^{\mathrm{TM}}$ device. Eur J Clin Nutr. 2005;59(5):651-657.

14. Tissot S, Delafosse B, Bertrand O, Bouffard Y, Viale J, Annat G. Clinical validation of the Deltatrac monitoring system in mechanically ventilated patients. Intens Care Med. 1995;21(2):149-153.

15. Júdice PB, Hamilton MT, Sardinha LB, Zderic TW, Silva AM. What is the metabolic and energy cost of sitting, standing and sit/stand transitions? Eur J Appl Physiol. $2016 ; 116(2): 263-273$.

16. Puyau MR, Adolph AL, Vohra FA, Zakeri I, Butte NF. Prediction of activity energy expenditure using accelerometers in children. Med Sci Sports Exer. 2004;36(9):16251631

17. Markwald RR, Melanson EL, Smith MR, et al. Impact of insufficient sleep on total daily energy expenditure, food intake, and weight gain. Proc Natl Acad Sci U S A. 2013;110(14):5695-5700.

18. Wells J, Fuller N. Precision and accuracy in a metabolic monitor for indirect calorimetry. Eur J Clin Nutr. 1998;52(7):536-540. 
19. Miodownik S, Melendez J, Carlon VA, Burda B. Quantitative methanol-burning lung model for validating gas-exchange measurements over wide ranges of. $J$ Appl Physiol. $1998 ; 84(6): 2177-2182$.

20. Elia M, Livesey G. Theory and validity of indirect calorimetry during net lipid synthesis. Am J Clin Nutr. 1988;47(4):591-607.

21. Ravussin E, Bogardus C. Relationship of genetics, age, and physical fitness to daily energy expenditure and fuel utilization. Am J Clin Nutr. 1989;49(5):968-975.

22. Nieman DC, Austin MD, Dew D, Utter AC. Validity of COSMED's quark CPET mixing chamber system in evaluating energy metabolism during aerobic exercise in healthy male adults. Res Sports Med. 2013;21(2):136-145.

23. Ashcraft CM, Frankenfield DC. Validity test of a new open-circuit indirect calorimeter. JPEN. 2015;39(6):738-742.

24. Foss $\varnothing$, Hallen J. Validity and stability of a computerized metabolic system with mixing chamber. Int J Sports Med. 2005;26(07):569-575.

25. Rising R, Whyte K, Albu J, Pi-Sunyer X. Evaluation of a new whole room indirect calorimeter specific for measurement of resting metabolic rate. Nutr Metab. $2015 ; 12(1): 1$.

26. Carter J, Jeukendrup AE. Validity and reliability of three commercially available breath-by-breath respiratory systems. Eur J Appl Physiol. 2002;86(5):435-441.

27. Rietjens G, Kuipers H, Kester A, Keizer H. Validation of a computerized metabolic measurement system (Oxycon-Pro $\left.{ }^{\circledR}\right)$ during low and high intensity exercise. Int $J$ Sports Med. 2001;22(04):291-294.

28. Bassett DR, Howley ET, Thompson DL, et al. Validity of inspiratory and expiratory methods of measuring gas exchange with a computerized system. J Appl Physiol. 2001;91(1):218-224. 
29. Gore CJ, Clark RJ, Shipp NJ, Van Der Ploeg GE, Withers RT. CPX/D underestimates VO (2) in athletes compared with an automated Douglas bag system. Med Sci Sports Exer 2003;35(8):1341-1347.

30. Salminen R, Aunola S, Mälkiä E, Vuori I. Computerized breath-by-breath analysis of respiratory variables during exercise. Med Prog Technol. 1981;9(1):27-32.

31. SchoellerDA. The effect of holiday weight gain on body weight. Physiol Behav. 2014;134:66-69.

32. Kien CL,Bunn JY, Ugrasbul F. Increasing dietary palmitic acid decreases fat oxidation and daily energy expenditure. Am J Clin Nutr. 2005;82(2):320-326.

33. Cooper JA, Watras AC, Shriver T, Adams AK, Schoeller DA. Influence of dietary fatty acid composition and exercise on changes in fat oxidation from a high-fat diet. $J$ Appl Physiol. 2010;109(4):1011-1018.

34. Hawkins K, Hansen K, Schoeller D, Cooper J. Effect of exercise on the diurnal variation in energy substrate use during a high-fat diet. Eur J Appl Physiol. 2012;112(11):3775-3785.

35. HibiM, Oishi S, Matsushita M, et al. Brown adipose tissue is involved in diet-induced thermogenesis and whole-body fat utilization in healthy humans. Int J Obes. 2016;40(11):1655-1661.

36. Murgatroyd P, Davies H, Prentice A. Intra-individual variability and measurement noise in estimates of energy expenditure by whole body indirect calorimetry. $\mathrm{Br} J$ Nutr. 1987;58(03):347-356. 
Table 1. Sites and characteristics of the twelve instruments tested at eleven international study sites

\begin{tabular}{|c|c|c|c|c|c|c|}
\hline \multirow[b]{2}{*}{$\begin{array}{c}\text { Instrumen } \\
t\end{array}$} & \multirow[b]{2}{*}{ Center } & \multirow[b]{2}{*}{ Location } & \multirow[b]{2}{*}{$\begin{array}{c}\text { Age of } \\
\text { Instrumen } \\
\text { t (years) }\end{array}$} & \multirow[b]{2}{*}{$\begin{array}{l}\text { Geographi } \\
\text { c Elevation } \\
\text { (ft) }\end{array}$} & \multicolumn{2}{|c|}{ Burn Environment } \\
\hline & & & & & $\begin{array}{c}\text { Average } \\
\text { Humidit } \\
\text { y (\%)* }\end{array}$ & $\begin{array}{c}\text { Average } \\
\text { Temperature }\left({ }^{0} \mathrm{C}\right)\end{array}$ \\
\hline $\begin{array}{c}\text { Vmax } \\
\text { Encore } \\
\text { System } \\
(\mathrm{Vmax}) \S\end{array}$ & $\begin{array}{l}\text { CS Mott } \\
\text { Children's } \\
\text { Hospital }\end{array}$ & $\begin{array}{c}\text { Ann Arbor, } \\
\text { Michigan, } \\
\text { USA }\end{array}$ & 4 & 629 & 24.8 & 23.7 \\
\hline $\begin{array}{c}\text { Cosmed } \\
\text { Quark } \\
\text { CPET } \\
\text { (Cosmed1) }\end{array}$ & $\begin{array}{l}\text { Georgia } \\
\text { State } \\
\text { University }\end{array}$ & $\begin{array}{l}\text { Atlanta, } \\
\text { Georgia, } \\
\text { USA }\end{array}$ & 4.5 & 1102 & 43.9 & 23 \\
\hline $\begin{array}{c}\text { Cosmed } \\
\text { Quark } \\
\text { CPET } \\
(\text { Cosmed } 2)\end{array}$ & $\begin{array}{l}\text { Loyola } \\
\text { University } \\
\text { of Chicago }\end{array}$ & $\begin{array}{l}\text { Maywood, } \\
\text { Illinois, } \\
\text { USA }\end{array}$ & 6 & 636 & 38.1 & 24.4 \\
\hline $\begin{array}{c}\text { Max-II } \\
\text { Metabolic } \\
\text { Systems } \\
\text { (Max-II) }\end{array}$ & $\begin{array}{c}\text { Penningto } \\
n\end{array}$ & Baton & 7 & & 45 & 23 \\
\hline $\begin{array}{c}\text { DeltaTrac } \\
\text { II } \\
\text { Metabolic } \\
\text { Monitor } \\
\text { (DTC1) } \\
\end{array}$ & $\begin{array}{c}\text { Biomedica } \\
1 \text { Research } \\
\text { Center }\end{array}$ & $\begin{array}{l}\text { Rouge, } \\
\text { Louisiana, } \\
\text { USA }\end{array}$ & $\geq 15$ & 65 & 45.5 & 21 \\
\hline $\begin{array}{c}\text { Parvo } \\
\text { Medics } \\
\text { trueOne } \\
\mathbf{2 4 0 0} \\
(\text { Parvo1) }\end{array}$ & $\begin{array}{l}\text { University } \\
\text { Cof } \\
\text { Delorado- }\end{array}$ & $\begin{array}{c}\text { Denver, } \\
\text { Colorado, } \\
\text { USA }\end{array}$ & 1 & 5367 & 44.9 & 25.0 \\
\hline $\begin{array}{c}\text { Parvo } \\
\text { Medics } \\
\text { trueOne } \\
\mathbf{2 4 0 0} \\
(\text { Parvo } 2)\end{array}$ & $\begin{array}{l}\text { University } \\
\text { of Georgia }\end{array}$ & $\begin{array}{l}\text { Athens, } \\
\text { Georgia, } \\
\text { USA }\end{array}$ & 1 & 761 & 53 & 24.5 \\
\hline $\begin{array}{c}\text { DeltaTrac } \\
\text { II } \\
\text { Metabolic } \\
\text { Monitor } \\
\text { (DTC2) } \\
\end{array}$ & $\begin{array}{l}\text { University } \\
\text { of } \\
\text { Wisconsin } \\
\text {-Madison }\end{array}$ & $\begin{array}{l}\text { Madison, } \\
\text { Wisconsin, } \\
\text { USA }\end{array}$ & 16 & 892 & 26 & 22.8 \\
\hline $\begin{array}{c}\text { Jaeger } \\
\text { Oxycon } \\
\text { Pro } \\
\text { (Oxycon1) } \\
\end{array}$ & $\begin{array}{c}\text { Lund } \\
\text { University }\end{array}$ & $\begin{array}{l}\text { Lund, } \\
\text { Sweden }\end{array}$ & 4 & 167 & 35.9 & 22.6 \\
\hline $\begin{array}{c}\text { Jaeger } \\
\text { Oxycon } \\
\text { Pro } \\
\text { (Oxycon } 2)\end{array}$ & $\begin{array}{l}\text { CIRO- } \\
\text { Center of } \\
\text { Expertise } \\
\text { for }\end{array}$ & $\begin{array}{c}\text { Horn, } \\
\text { Netherland } \\
\text { s }\end{array}$ & 15 & 101 & 62.5 & 21.5 \\
\hline
\end{tabular}

This is the author manuscript accepted for publication and has undergone full peer review but has not been through the copyediting, typesetting, pagination and proofreading process, which may lead to differences between this version and the Version of Record. Please cite this article as doi: 10.1002/ncp.10070.

This article is protected by copyright. All rights reserved. 


\begin{tabular}{|c|c|c|c|c|c|c|}
\hline & $\begin{array}{l}\text { Chronic } \\
\text { Organ } \\
\text { failure }\end{array}$ & & & & & \\
\hline $\begin{array}{c}\text { Omnical } \\
\text { (Omnicall) }\end{array}$ & $\begin{array}{c}\text { Topsport } \\
\text { Expertise } \\
\text { and } \\
\text { Innovative } \\
\text { Centre } \\
\text { (TEIC) }\end{array}$ & $\begin{array}{l}\text { Sittard, } \\
\text { Netherland } \\
\text { s }\end{array}$ & 2 & 153 & 64.1 & 17.1 \\
\hline $\begin{array}{c}\text { Omnical } \\
\text { (Omnical2) }\end{array}$ & $\begin{array}{l}\text { Maastricht } \\
\text { University } \\
\text { Medical } \\
\text { Center }\end{array}$ & $\begin{array}{l}\text { Maastricht, } \\
\text { Netherland } \\
\text { s }\end{array}$ & 6 & 183 & 57.1 & 19.7 \\
\hline
\end{tabular}

2 Table 1. $\S$ For the purpose of easy reference to each of the metabolic carts in this manuscript, each have been 3 given a short name with/without a number in parentheses.

$4 *$ The average humidity and temperature for each test site defines the average of humidity (\%) and temperature $5 \quad\left({ }^{0} \mathrm{C}\right)$ during methanol burns done in all 8 time points of the two test days inside of the labs where testing 6 occurred.

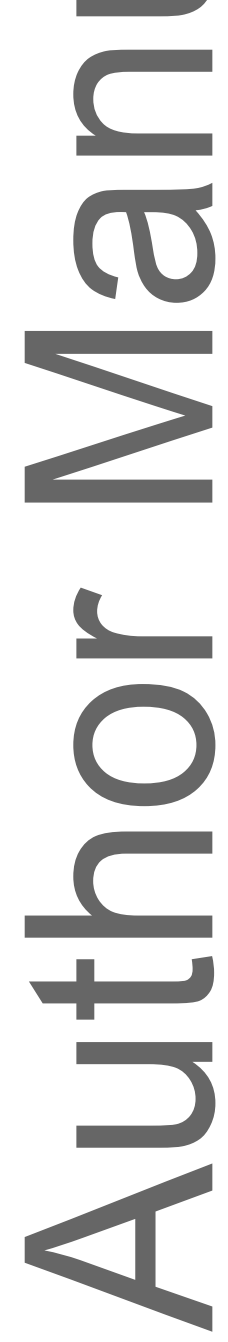


Table 2. Accuracy results of the twelve instruments tested based on the calculated percent of relative error (\%RE) in measuring the three variables of interest (RER, $\mathrm{O}_{2}$ Recovery, and $\mathrm{CO}_{2}$ Recovery)

\begin{tabular}{|c|c|c|c|c|c|c|c|c|c|c|c|}
\hline \multirow{2}{*}{ Inst. } & \multicolumn{3}{|c|}{$\mathrm{O}_{2}$ Recovery $(\%)$} & \multirow{2}{*}{ Inst. } & \multicolumn{3}{|c|}{$\mathrm{CO}_{2}$ Recovery $(\%)$} & \multirow{2}{*}{ Inst. } & \multicolumn{3}{|c|}{ RER } \\
\hline & $\bar{X}$ & \%RE & Rk & & $\bar{X} \pm \mathbf{S D}$ & $\%$ RE & Rk & & $\bar{X} \pm$ SD & $\%$ RE & Rk \\
\hline $\begin{array}{c}\text { Omnica } \\
11\end{array}$ & & $\begin{array}{c}0.094 \\
*\end{array}$ & 1 & Parvo2 & $\begin{array}{c}100.1 \pm 3 \\
.2\end{array}$ & $\begin{array}{l}0.144 \\
*\end{array}$ & 1 & $\begin{array}{c}\text { Omnica } \\
12\end{array}$ & $\begin{array}{c}0.667 \pm 0.0 \\
02\end{array}$ & $\begin{array}{l}0.001 \\
*\end{array}$ & 1 \\
\hline Parvo1 & & $\begin{array}{c}- \\
0.653 \\
*\end{array}$ & 2 & Parvo1 & $\begin{array}{c}0.99 \pm 0 . \\
02\end{array}$ & $\begin{array}{c}- \\
0.525 \\
*\end{array}$ & 2 & Parvo1 & $\begin{array}{c}0.668 \pm 0.0 \\
06\end{array}$ & $\begin{array}{c}0.126 \\
*\end{array}$ & 2 \\
\hline $\begin{array}{l}\text { Cosme } \\
\text { d2 }\end{array}$ & & 0.250 & 3 & $\begin{array}{l}\text { Cosme } \\
\text { d2 }\end{array}$ & $\begin{array}{c}100.7 \pm 1 \\
.7\end{array}$ & $\begin{array}{c}0.666 \\
*\end{array}$ & 3 & $\begin{array}{l}\text { Cosme } \\
\text { d2 }\end{array}$ & $\begin{array}{c}0.673 \pm 0.0 \\
05\end{array}$ & $\begin{array}{c}0.927 \\
*\end{array}$ & 3 \\
\hline DTC2 & & $\begin{array}{l}0.794 \\
*\end{array}$ & 4 & DTC1 & $\begin{array}{c}100.7 \pm 1 \\
.5\end{array}$ & $\begin{array}{l}0.702 \\
*\end{array}$ & 4 & Parvo2 & $\begin{array}{c}0.660 \pm 0.0 \\
05\end{array}$ & $\begin{array}{c}- \\
1.034 \\
* \neq\end{array}$ & 4 \\
\hline Parvo2 & & $\begin{array}{l}1.185 \\
*\end{array}$ & 5 & $V \max$ & $\begin{array}{c}98.4 \pm 2 . \\
1\end{array}$ & $\begin{array}{c}- \\
1.615 \\
*\end{array}$ & 5 & $\begin{array}{c}\text { Omnica } \\
11\end{array}$ & $\begin{array}{c}0.677 \pm 0.0 \\
03\end{array}$ & $\begin{array}{c}1.546 \\
*\end{array}$ & 5 \\
\hline$V \max$ & & $\begin{array}{c}1.804 \\
*\end{array}$ & 6 & $\begin{array}{c}\text { Omnica } \\
11\end{array}$ & $\begin{array}{c}101.6 \pm 0 \\
.8\end{array}$ & $\begin{array}{c}1.640 \\
*\end{array}$ & 6 & Max-II & $\begin{array}{c}0.652 \pm 0.0 \\
22\end{array}$ & -2.226 & 6 \\
\hline $\begin{array}{l}\text { Oxycon } \\
2\end{array}$ & & 2.051 & 7 & DTC2 & $\begin{array}{c}98.1 \pm 3 . \\
8\end{array}$ & $\begin{array}{c}1.874 \\
*\end{array}$ & 7 & DTC2 & $\begin{array}{c}0.649 \pm 0.0 \\
20\end{array}$ & -2.649 & 7 \\
\hline $\begin{array}{l}\text { Cosme } \\
\text { d1 }\end{array}$ & .2 & 2.469 & 8 & $\begin{array}{c}\text { Omnica } \\
12\end{array}$ & $\begin{array}{c}103.6 \pm 1 \\
.3\end{array}$ & 3.647 & 8 & $\begin{array}{c}\text { Oxycon } \\
1\end{array}$ & $\begin{array}{c}0.649 \pm 0.0 \\
07\end{array}$ & -2.705 & 8 \\
\hline DTC1 & & $\begin{array}{c}- \\
2.619\end{array}$ & 9 & $\begin{array}{c}\text { Cosme } \\
\text { d1 }\end{array}$ & $\begin{array}{c}95.7 \pm 1 . \\
2\end{array}$ & $\begin{array}{c}- \\
4.293\end{array}$ & 9 & Vmax & $\begin{array}{c}0.645 \pm 0.0 \\
23\end{array}$ & -3.221 & 9 \\
\hline $\begin{array}{c}\text { Omnica } \\
12\end{array}$ & & 3.647 & $\begin{array}{l}1 \\
0\end{array}$ & $\begin{array}{l}\text { Oxycon } \\
2\end{array}$ & $\begin{array}{c}104.4 \pm 6 \\
.7\end{array}$ & 4.368 & $\begin{array}{l}1 \\
0\end{array}$ & DTC1 & $\begin{array}{c}0.689 \pm 0.0 \\
08\end{array}$ & 3.420 & $\begin{array}{l}1 \\
0\end{array}$ \\
\hline Max-II & & 6.970 & $\begin{array}{l}1 \\
1\end{array}$ & Max-II & $\begin{array}{c}104.5 \pm 2 \\
.2\end{array}$ & 4.493 & $\begin{array}{l}1 \\
1\end{array}$ & $\begin{array}{c}\text { Cosme } \\
\text { d1 }\end{array}$ & $\begin{array}{c}0.626 \pm 0.0 \\
14\end{array}$ & -6.089 & $\begin{array}{l}1 \\
1\end{array}$ \\
\hline $\begin{array}{c}\text { Oxycon } \\
1\end{array}$ & & $\begin{array}{c}- \\
8.615\end{array}$ & $\begin{array}{l}1 \\
2\end{array}$ & $\begin{array}{c}\text { Oxycon } \\
1\end{array}$ & $\begin{array}{c}88.9 \pm 2 . \\
6\end{array}$ & $\begin{array}{c}- \\
11.10 \\
3\end{array}$ & $\begin{array}{l}1 \\
2\end{array}$ & $\begin{array}{l}\text { Oxycon } \\
2\end{array}$ & $\begin{array}{c}0.712 \pm 0.0 \\
40\end{array}$ & 6.755 & $\begin{array}{l}1 \\
2\end{array}$ \\
\hline
\end{tabular}

Table 2. Inst., Instrument; \%RE, Percent of Relative Error; RER, Respiratory Exchange Ratio; Rk, Rank; SD, Standard Deviation; $\bar{X}$, Average of measured values by the instruments throughout the 8 burns. Instruments rankings (best to worst) are based on $\% \mathrm{RE}(\% \mathrm{RE}=$ $\frac{\text { (Average of measured values-Theoretical value) }}{\text { Theoretical Value }} \times 100$ ); which explains the difference of the average values

This is the author manuscript accepted for publication and has undergone full peer review but has not been through the copyediting, typesetting, pagination and proofreading process, which may lead to differences between this version and the Version of Record. Please cite this article as doi: 10.1002/ncp.10070.

This article is protected by copyright. All rights reserved. 
measured by the instruments from theoretical. Theoretical values are 0.667 (for RER), and $100 \%$ (for $\mathrm{O}_{2}$ and $\mathrm{CO}_{2}$ recoveries).

* denotes accurate instrument based on a $\% \mathrm{RE} \leq 2 \%$.

\$ Negative $\%$ RE vallues on this table indicate that the calculated averages for the corresponding instruments were less than the theoretical value.

Table 3. Reliability results of the twelve instruments tested based on the calculated coefficient of variation $(\mathrm{CV} \%)$ in measuring the three variables of interest (RER, $\mathrm{O}_{2}$ Recovery, and $\mathrm{CO}_{2}$ Recovery)

\begin{tabular}{|c|c|c|c|c|c|c|c|c|}
\hline \multirow{2}{*}{ Inst. } & \multicolumn{2}{|c|}{$\%$ Recovery $\mathrm{O}_{2}$} & \multirow{2}{*}{ Inst. } & \multicolumn{2}{|c|}{$\%$ Recovery $\mathrm{CO}_{2}$} & \multirow{2}{*}{ Inst. } & \multicolumn{2}{|c|}{ RER } \\
\hline & CV (\%) & $\mathbf{R k}$ & & CV (\%) & $\mathbf{R k}$ & & CV (\%) & $\mathbf{R k}$ \\
\hline Omnical & $.75^{*}$ & 1 & Omnicall & $0.76^{*}$ & 1 & Omnical2 & $0.23 *$ & 1 \\
\hline Omnica & $1.26^{*}$ & 2 & Omnical2 & $1.21 *$ & 2 & Omnical1 & $0.49 *$ & 2 \\
\hline Parvo 1 & $.56^{*}$ & 3 & Cosmed 1 & $1.22 *$ & 3 & Cosmed2 & $0.68 *$ & 3 \\
\hline DTC1 & $.76^{*}$ & 4 & DTC1 & $1.47 *$ & 4 & Parvo2 & $0.75^{*}$ & 4 \\
\hline Cosmed & $10^{*}$ & 5 & Cosmed2 & $1.65^{*}$ & 5 & Parvo1 & $0.86^{*}$ & 5 \\
\hline Cosmed & $2.18^{*}$ & 6 & Parvo1 & $1.93 *$ & 6 & Oxycon1 & $1.05 *$ & 6 \\
\hline DTC2 & $2.35^{*}$ & 7 & $V \max$ & $2.09 *$ & 7 & DTC1 & $1.13^{*}$ & 7 \\
\hline Parvo2 & $2.89 *$ & 8 & Max-II & $2.14^{*}$ & 8 & Cosmed1 & $2.28^{*}$ & 8 \\
\hline Oxycon & .42 & 9 & Oxycon1 & $2.97 *$ & 9 & DTC2 & 3.01 & 9 \\
\hline Max-II & 3.69 & 10 & Parvo2 & 3.18 & 10 & Max-II & 3.42 & 10 \\
\hline$V \max$ & 4.97 & 11 & DTC2 & 3.84 & 11 & $V \max$ & 3.50 & 11 \\
\hline Oxycon & 7.31 & 12 & Oxycon2 & 6.46 & 12 & Oxycon2 & 5.49 & 12 \\
\hline
\end{tabular}

Table 3. CV, Coefficient of Variation; Inst., Instrument; RER, Respiratory Exchange Ratio; Rk, Rank. Instruments rankings (best to worst) are based on $\mathrm{CV}$ which was used to assess reliability of measurements by each instrument.

* denotes reliable instrument based on a $\mathrm{CV} \leq 3 \%$.

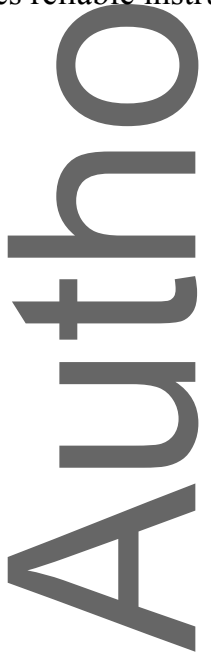


Table 4. Instrument Characteristics

\begin{tabular}{|c|c|c|c|c|c|c|c|}
\hline \multicolumn{3}{|c|}{\begin{tabular}{c|c} 
Instrumen & $\begin{array}{c}\text { Calibration Gas } \\
\text { Concentration }\end{array}$
\end{tabular}} & \multirow{2}{*}{$\begin{array}{c}\text { Averag } \\
\text { e Flow } \\
\text { Rate } \\
\text { (L/min) }\end{array}$} & \multicolumn{2}{|c|}{ Gas Analyzer } & \multirow{2}{*}{$\begin{array}{l}\text { Flow Rate } \\
\text { Calibratio } \\
\text { n Method }\end{array}$} & \multirow{2}{*}{$\begin{array}{c}\text { Flow Rate } \\
\text { Analyzer } \\
\text { System }\end{array}$} \\
\hline t & , & $\mathrm{CO}_{2}$ & & $\mathbf{O}_{2}$ & $\mathrm{CO}_{2}$ & & \\
\hline$V \max$ & & $4.0 \%$ & 46.7 & $\begin{array}{l}\text { Electro- } \\
\text { chemical } \\
\text { fuel cell }\end{array}$ & $\begin{array}{c}\text { Non- } \\
\text { Disperse } \\
\text { Infrared, } \\
\text { Thermopil } \\
\text { e }\end{array}$ & $\begin{array}{l}\text { 2L syringe } \\
\text { push and } \\
\text { pull motion } \\
\text { x } 10 \text { times }\end{array}$ & $\begin{array}{l}\text { Mass Flow } \\
\text { Sensor }\end{array}$ \\
\hline Cosmed 1 & & $4.98 \%$ & 30.97 & $\begin{array}{c}\text { Paramagneti } \\
\mathrm{c}\end{array}$ & $\begin{array}{l}\text { Digital } \\
\text { Infrared }\end{array}$ & $\begin{array}{l}\text { 3L syringe } \\
\text { push and } \\
\text { pull motion } \\
\text { x } 10 \text { times }\end{array}$ & $\begin{array}{c}\text { ID18 } \\
\text { turbine } \\
\text { flowmeter; } \\
\text { separate } \\
\text { Canopy } \\
\text { unit }\end{array}$ \\
\hline Cosmed & & $5 \%$ & 28.02 & $\begin{array}{c}\text { Paramagneti } \\
\text { c }\end{array}$ & $\begin{array}{l}\text { Digital } \\
\text { Infrared }\end{array}$ & $\begin{array}{l}\text { 2L syringe } \\
\text { push and } \\
\text { pull motion } \\
\text { x } 10 \text { times }\end{array}$ & $\begin{array}{l}\text { Turbine } \\
2000\end{array}$ \\
\hline Max-I & $19.02 \%$ & $\begin{array}{c}0.028 \\
\%\end{array}$ & 25.4 & $\begin{array}{c}\text { Paramagneti } \\
\mathrm{c}\end{array}$ & Infrared & $\begin{array}{l}\text { 3L syringe } \\
\text { with non- } \\
\text { rebreathing } \\
\text { valve, push } \\
\text { and pull } \\
\text { motion x } 5 \\
\text { times } \\
\end{array}$ & $\begin{array}{l}\text { Pneumotac } \\
\mathrm{h} \text { (pressure } \\
\text { transducer) }\end{array}$ \\
\hline DTC1 & & $5 \%$ & 42.10 & $\begin{array}{c}\text { Paramagneti } \\
\text { c }\end{array}$ & Infrared & $\begin{array}{l}\text { Flowrate } \\
\text { assumed to } \\
\text { be constant } \\
\text { throughout } \\
\text { the test } \\
\text { using } \mathrm{CO}_{2} \\
\text { recovery } \\
\text { from } \\
\text { ethanol }\end{array}$ & $\begin{array}{c}\text { Not } \\
\text { applicable }\end{array}$ \\
\hline Parvo1 & & $4.05 \%$ & 13.6 & $\begin{array}{c}\text { Paramagneti } \\
\mathrm{c}\end{array}$ & $\begin{array}{l}\text { Digital } \\
\text { Infrared }\end{array}$ & $\begin{array}{l}\text { 3L syringe } \\
\text { push and } \\
\text { pull motion } \\
\text { x } 10 \text { times }\end{array}$ & $\begin{array}{c}\text { Rudolph } \\
\text { heated } \\
\text { pneumotac } \\
\text { h }\end{array}$ \\
\hline Parvo2 & $16 \%$ & $4.05 \%$ & 13.6 & $\begin{array}{c}\text { Paramagneti } \\
\text { c }\end{array}$ & $\begin{array}{l}\text { Digital } \\
\text { Infrared }\end{array}$ & $\begin{array}{l}\text { 3L syringe } \\
\text { push and } \\
\text { pull motion } \\
\text { x } 10 \text { times }\end{array}$ & $\begin{array}{c}\text { Rudolph } \\
\text { heated } \\
\text { pneumotac } \\
\mathrm{h}\end{array}$ \\
\hline DTC2 & $96 \%$ & $4 \%$ & 36.2 & $\begin{array}{l}\text { Paramagneti } \\
\mathrm{c}\end{array}$ & Infrared & $\begin{array}{c}\mathrm{MeOH} \\
\text { burns done } \\
\text { weekly and }\end{array}$ & $\begin{array}{c}36.2 \mathrm{~L} / \mathrm{m} \\
\text { STP. Fixed } \\
\text { flow rate }\end{array}$ \\
\hline
\end{tabular}




\begin{tabular}{|c|c|c|c|c|c|c|}
\hline & & & & & $\begin{array}{l}\text { averaged } \\
\text { over three } \\
\text { previous } \\
\text { weeks. }\end{array}$ & $\begin{array}{l}\text { using } \\
\text { critical } \\
\text { orifice } \\
\text { design }\end{array}$ \\
\hline Oxycont $15.96 \%$ & $4.95 \%$ & 40 & $\begin{array}{c}\text { Paramagneti } \\
\mathrm{c}\end{array}$ & Infrared & $\begin{array}{l}\text { Internal, } \\
\text { automatic }\end{array}$ & $\begin{array}{l}\text { Triple-V } \\
\text { (flat fan) }\end{array}$ \\
\hline Oxycon 2 & $\begin{array}{c}4.5 \\
(5,000 \\
\text { vol } \%)\end{array}$ & 38.88 & $\begin{array}{l}\text { Chemical } \\
\text { fuel cell }\end{array}$ & $\begin{array}{c}\text { Infrared } \\
\text { absorption }\end{array}$ & $\begin{array}{l}\text { Automated } \\
\text { flow } \\
\text { calibration } \\
\text { at rates of } \\
0.2 \text { and } 2.0 \\
\mathrm{~L} / \mathrm{sec}\end{array}$ & $\begin{array}{l}\text { Triple-V } \\
\text { (flat fan) }\end{array}$ \\
\hline Omnical1 & $0.8 \%$ & 202.8 & $\begin{array}{c}\text { ABB H\&B } \\
\text { MAGNOS* } \\
\text { dumbbell } \\
\text { type } \\
\text { paramagneti } \\
\text { c }\end{array}$ & $\begin{array}{l}\text { ABB H\&B } \\
\text { URAS* } \\
\text { infrared }\end{array}$ & $\begin{array}{l}\text { Periodical } \\
\text { calibration } \\
\text { with } \\
\text { certified } \\
\text { flow meter } \\
\text { in series }\end{array}$ & $\begin{array}{c}\text { Uni- } \\
\text { directional } \\
\text { dry bellows } \\
\text { flow meter } \\
\text { with digital } \\
\text { counter }\end{array}$ \\
\hline Omnical2 & $0.8 \%$ & 36.4 & $\begin{array}{c}\text { ABB H\&B } \\
\text { MAGNOS* } \\
\text { dumbbell } \\
\text { type } \\
\text { paramagneti } \\
\text { c }\end{array}$ & $\begin{array}{c}\text { ABB H\&B } \\
\text { URAS* } \\
\text { infrared }\end{array}$ & $\begin{array}{c}\text { Periodical } \\
\text { calibration } \\
\text { with } \\
\text { certified } \\
\text { flow meter } \\
\text { in series }\end{array}$ & $\begin{array}{c}\text { Uni- } \\
\text { directional } \\
\text { dry bellows } \\
\text { flow meter } \\
\text { with digital } \\
\text { counter }\end{array}$ \\
\hline
\end{tabular}

Table 4. ID18, Inside Diameter $18 \mathrm{~mm}$; MeOH, Methanol; STP, Standard Temperature and Pressure; Vol, Volume.

* ABB H\&B MAGNOS and ABB H\&B URAS are brands/models of the analyzers.

Table 5. Correlation Matrix

\begin{tabular}{|c|c|c|c|c|c|c|c|c|}
\hline & $\begin{array}{c}\text { Correlati } \\
\text { on } \\
\text { Coefficie } \\
\text { nts }\end{array}$ & $\begin{array}{c}\% 02 \\
\text { Recove } \\
\text { ry }\end{array}$ & $\begin{array}{c}\% \mathrm{CO} 2 \\
\text { Recove } \\
\text { ry }\end{array}$ & $\begin{array}{c}\text { Temperatu } \\
\text { re }\end{array}$ & $\begin{array}{c}\text { Humidi } \\
\text { ty }\end{array}$ & $\begin{array}{c}\text { Amoun } \\
t \text { of } \\
\text { Methan } \\
\text { ol } \\
\text { Burned }\end{array}$ & Age & $\begin{array}{c}\text { Geograp } \\
\text { hic } \\
\text { Elevation }\end{array}$ \\
\hline RER & & $\begin{array}{c}-0.37 \\
<0.001 *\end{array}$ & $\begin{array}{c}0.46 \\
<0.001 *\end{array}$ & $\begin{array}{c}-0.29 \\
0.005^{*}\end{array}$ & $\begin{array}{c}0.37 \\
<0.001 *\end{array}$ & $\begin{array}{l}-0.23 \\
0.02 *\end{array}$ & $\begin{array}{c}0.26 \\
0.01 \\
*\end{array}$ & $\begin{array}{l}-0.01 \\
0.94\end{array}$ \\
\hline $\begin{array}{c}\% \mathrm{O} 2 \\
\text { Recovery }\end{array}$ & & & $\begin{array}{c}0.66 \\
<0.001 *\end{array}$ & $\begin{array}{l}0.02 \\
0.86\end{array}$ & $\begin{array}{l}0.09 \\
0.36\end{array}$ & $\begin{array}{c}-0.07 \\
0.50\end{array}$ & $\begin{array}{c}- \\
0.07 \\
0.49\end{array}$ & $\begin{array}{l}-0.05 \\
0.64\end{array}$ \\
\hline $\begin{array}{c}\% \mathrm{CO} 2 \\
\text { Recovery }\end{array}$ & $\begin{array}{c}\mathrm{R}^{2} \\
\mathrm{p} \text {-value }\end{array}$ & & & $\begin{array}{l}-0.22 \\
0.03 *\end{array}$ & $\begin{array}{c}0.39 \\
<0.001 *\end{array}$ & $\begin{array}{l}-0.27 \\
<0.01 *\end{array}$ & $\begin{array}{l}0.14 \\
0.19\end{array}$ & $\begin{array}{c}-0.05 \\
0.63\end{array}$ \\
\hline $\begin{array}{c}\text { Temperatu } \\
\text { re }\end{array}$ & & & & & $\begin{array}{c}-0.65 \\
<0.001 *\end{array}$ & $\begin{array}{c}0.50 \\
<0.001 *\end{array}$ & $\begin{array}{l}0.12 \\
0.23\end{array}$ & $\begin{array}{c}0.33 \\
0.001 *\end{array}$ \\
\hline Humidity & alue & & & & & $\begin{array}{c}-0.34 \\
<0.001 *\end{array}$ & $\begin{array}{l}0.03 \\
0.75\end{array}$ & $\begin{array}{c}-0.45 \\
<0.001 *\end{array}$ \\
\hline $\begin{array}{c}\text { Amount of } \\
\text { Methanol } \\
\text { Burned } \\
\text { Age }\end{array}$ & $\begin{array}{c}\mathrm{R}^{2} \\
\mathrm{p} \text {-value } \\
\mathrm{R}^{2}\end{array}$ & & & & & & $\begin{array}{l}0.15 \\
0.15\end{array}$ & $\begin{array}{l}0.13 \\
0.22\end{array}$ \\
\hline
\end{tabular}




\section{Geographi $\quad \mathrm{R}^{2}$ \\ c Elevation p-value}

Table 5. RER, Respiratory Exchange Ratio.

* denotes significant correlation based on a p-value $\leq 0.05$.

\section{Figure captions:}

Figure 1. Six out of twelve instruments (Omnical1, Cosmed2, DTC2, Parvo1, Parvo2, Vmax) measured $\%$ recovery $\mathrm{O}_{2}$ with $\% \mathrm{RE} \leq 2 \%$ (inside the limits of upper and lower dashed lines).

* den

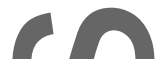

Figure l. Comparisons of $\%$ recovery $\mathrm{O}_{2}$ measured by the twelve instruments tested to the theoretical value for methanol

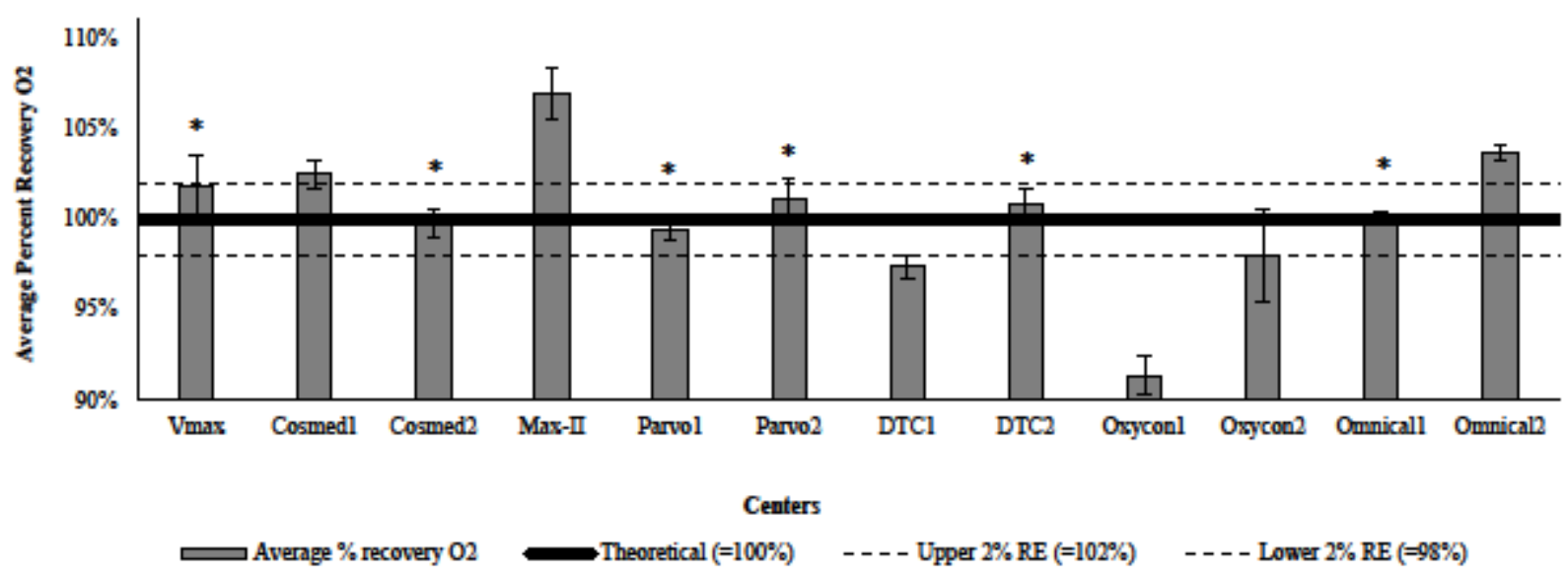

otes accurate instrument based on a $\% \mathrm{RE} \leq 2 \%$. 
Figure 2. Seven out of twelve instruments (Parvo2, Parvo 1, Cosmed2, DTC1, Vmax,

Omnical1, DTC2) measured $\%$ recovery $\mathrm{CO}_{2}$ with $\% \mathrm{RE} \leq 2 \%$ (inside the limits of upper and lower dashed lines).

* denotes accurate instrument based on a $\% \mathrm{RE} \leq 2 \%$.

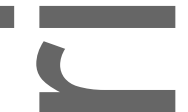

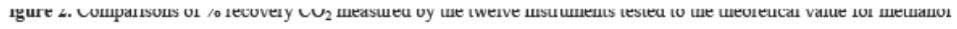
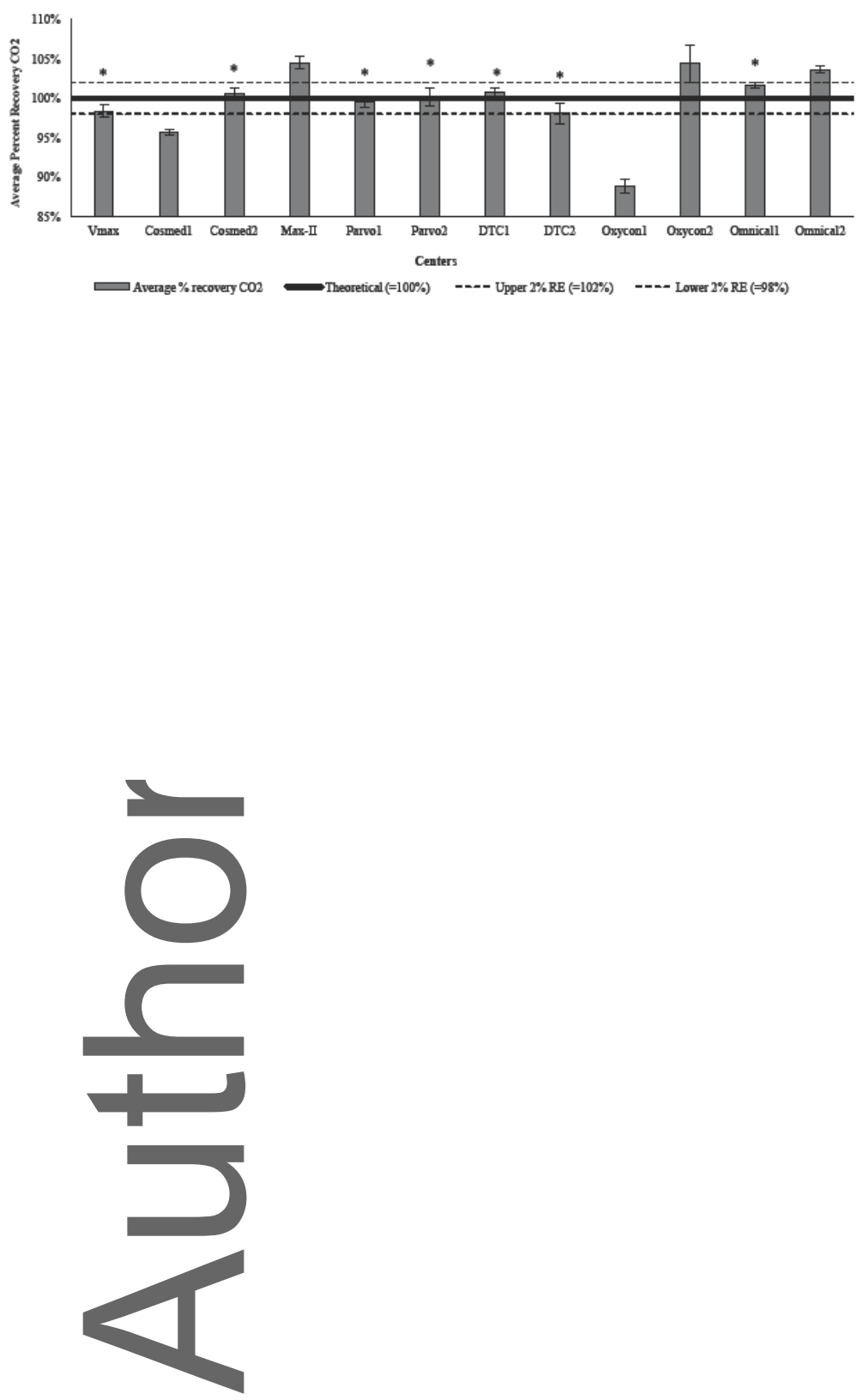
Figure 3. Five out of twelve instruments (Omnical2, Cosmed2, Parvo2, Omnical1 and Parvo1) measured RER with $\% \mathrm{RE} \leq 2 \%$ (inside the limits of upper and lower dashed lines).

* denotes accurate instrument based on a $\% \mathrm{RE} \leq 2 \%$.

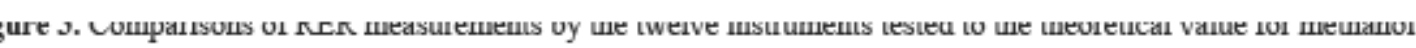

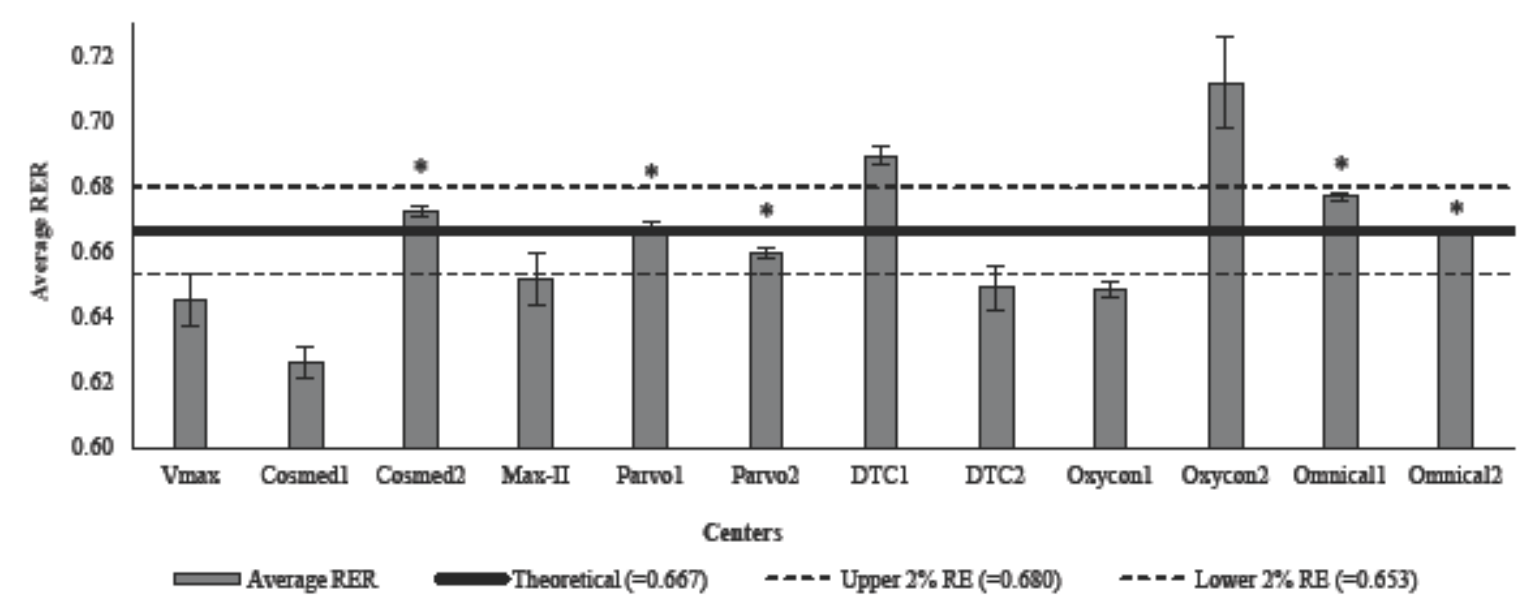

